\title{
Food patterns of Spanish schoolchildren and adolescents: The enKid Study
}

\author{
Lluís Serra-Majem ${ }^{1,2, *}$, Reina García-Closas ${ }^{3}$, Lourdes Ribas ${ }^{2}$, Carmen Pérez-Rodrigo ${ }^{4}$ and \\ Javier Aranceta $^{4}$ \\ 'Department of Clinical Sciences, University of Las Palmas de Gran Canaria, PO Box 550, E-35080 Las Palmas de \\ Gran Canaria, Spain: ${ }^{2}$ Community Nutrition Research Centre, Scientific Park of University of Barcelona, Spain: \\ ${ }^{3}$ Department of Preventive Medicine, University of la Laguna, Tenerife, Spain: ${ }^{4}$ Community Nutrition Unit, \\ Ayuntamiento de Bilbao, Spain
}

\begin{abstract}
Objective: To evaluate dietary habits and nutritional status of Spanish schoolchildren and adolescents.

Design: Cross-sectional study by face-to-face interview.

Methods: A random sample of 3534 people aged 2 to 24 years were interviewed by a team of 43 dietitians in the subjects' homes. Interviews included 24-hour recalls (a second 24-hour recall in 30\% of the sample), a food-frequency questionnaire and other questions including lifestyles, knowledge and food preferences.

Results: The participation rate was 68\%. Mean daily energy consumption was $2189 \mathrm{kcal}$ among males and $1781 \mathrm{kcal}$ among females, and the percentage of energy from fat and saturated fat was 39.8\% and 13.4\%, respectively, without any differences by gender. Of females, 95\% showed folic acid intakes below $200 \mu \mathrm{g} \mathrm{day}^{-1}$. Consumption expressed as food groups reflected a westernised Mediterranean pattern.

Conclusions: The enKid Study provides reliable and useful nutrition information for children and adolescents in Spain, having incorporated a rigorous methodological design within a representative sample.
\end{abstract}

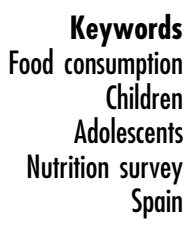

Infancy and adolescence constitute a period of undoubted nutritional interest for a variety of reasons.

1. It encompasses a phase where the promotion and consolidation of eating habits occur and, thus, is a potentially impressionable stage.

2. It constitutes a period of risk given the increased nutritional requirements for growth and development.

3. In Spain, it is in this population where modifications of the Mediterranean diet are most visible, as well as the transformation of dietary habits in which the food industry and restaurant establishments are gaining ground over home-prepared meals.

The majority of dietary information utilised in Spain comes from household or national availability surveys, which do not permit categorising information for children and adolescents. Moreover, the majority of nutrition surveys carried out at the regional level in our country exclude this population group. With the exception of certain studies conducted in communities or cities ${ }^{1-10}$, detailed information on dietary habits and nutritional status in children and youth does not exist in Spain. What is more, according to Gorgojo et al., several additional studies carried out in these age groups do not appear to have the required methodological rigour ${ }^{11}$.

For these reasons, it was considered necessary to conduct a nutrition survey in the Spanish population aged 2 to 24 years. This study would need to meet the demands and methodological requirements that would allow for the subsequent development and realisation of coherent intervention policies for this important and vulnerable population group.

The objective of this study was to evaluate the nutritional status of the Spanish population aged 2 to 24 years, and to determine the contribution of breakfast and ready-to-eat cereals (RTEC) in the diet.

\section{Methodology}

\section{Study design}

The study design was a population-based, cross-sectional study. 


\section{Sample}

The target population consisted of all inhabitants living in Spain aged 2 to 24 , and the sample population was derived from residents from 2 to 24 years of age registered in the Spanish official population census. The theoretical sample size was set at 5500 individuals, taking into account an anticipated $70 \%$ participation rate, which would result in a sample of approximately 3850 individuals. Calculations were made, within a 95\% confidence interval (CI), to ascertain the level of precision for estimates of parameters most likely to be compromised (micronutrients) in each stratum, as a function of the maximum sample size that the study permitted. Estimations were calculated for approximately 100 strata.

The age groups established were $2-5$ years, 6-9 years, 10-13 years, 14-17 years and 18-24 years.

The sampling technique included stratification according to geographical area and municipality size and randomisation into subgroups, with Spanish municipalities being the primary sampling units, and individuals within these municipalities comprising the final sample units. The distribution of the sample size among strata was proportional to cost (optimal fixed sampling) and to the contribution of strata to the total sample size. The defined geographical areas were Northeast zone (Catalunya, Aragon, Baleares Islands), Eastern zone (Valencia, Murcia), Southern zone (Andalucía), Central zone (Madrid, Castilla-La Mancha, Castilla-León, Extremadura), Northwest zone (Galicia, Asturias), Northern zone (Basque country, Cantabria, Rioja, Navarra) and the Canary Islands. The defined population groups by municipality size were $<10000$ inhabitants, $10000-50000$ inhabitants, $>50000-350000$ inhabitants and >350 000 inhabitants. All capitals of provinces having more than 350000 inhabitants were incorporated as part of the sample, and included: Madrid, Barcelona, Valencia, Sevilla, Zaragoza, Málaga, Bilbao and Las Palmas de Gran Canaria. The other municipalities incorporated into the sample were randomly selected from the remaining substrata (conglomerates). As the municipalities of each substratum were considered homogeneous, the number of towns/cities sampled within each substratum was determined by the cost and contribution that the substratum in question would provide to the total size of the sample. The number of persons sampled in each conglomerate was determined by optimal fixed sampling.

\section{Sampling}

The sample of the selected municipalities was solicited directly from each of them by the Carlos III Health Institute of the Spanish Ministry of Health and Consumption. After 12 months of negotiations, 20 of the 85 municipalities had to be substituted due to a lack of census information. These were replaced by other neighbouring municipalities that had similar character- istics to the original towns/cities sampled, and, as such, sampling was completed in December 1998.

\section{Questionnaires}

Dietary questionnaires and a global questionnaire incorporating questions related to socio-economic status, education level and lifestyle factors were utilised.

The dietary questionnaires used were: one 24-hour diet recall and a quantitative food-frequency questionnaire by subject; and a second 24-hour diet recall in 25-30\% of the sample. 24-hour recalls were administered throughout the year, in order to avoid the influence of seasonal variations. The questionnaires were conducted in the participant's home. To avoid bias brought on by day-today intake variability, the questionnaires were administered homogeneously from Monday to Sunday. In order to estimate volumes and portion sizes, the household measures found in the subject's own home were used. The administration of two questionnaires in a sub-sample allowed us to adjust intakes for random intra-individual variation using the method described by Liu et $a l^{12}$.

The food-frequency questionnaire design with 176 items was based on questionnaires previously utilised in earlier studies in the Basque Country ${ }^{13}$ and Madrid ${ }^{14}$. The questionnaire included specific items for the type and brand of RTEC consumed, as well as for the types of fat, sugar, processed foods and vitamin and mineral supplements.

The questionnaire about nutrition knowledge and opinions had been adapted from the Pan-European Study on Children's Views on Food and Nutrition, from the Children's Research Unit of the United Kingdom, and sponsored by the European Food Information Council (EUFIC).

Information on smoking habits, physical activity and alcohol intake was collected using specific questionnaires. Smoking habits were classified according to World Health Organisation criteria. The physical activity questionnaire had been adapted from the CINDI programme of the World Health Organisation, and from the questionnaire of the MARATHON group on physical activity and leisure time. The questionnaire on alcohol intake was also adopted, utilising the questionnaire of the Catalan Nutrition Survey $1992^{5}$.

\section{Anthropometric measures}

The anthropometric measures obtained were: weight, height, body mass index (BMI) (weight/height ${ }^{2}$ ), waist circumference, hip circumference, waist/hip index, arm circumference, head circumference and elbow width. Measurements were taken in the home of the participant during the interview. Participants were weighed without shoes and only wearing underclothes. Electronic weighing scales were used, which were periodically calibrated. Height was estimated using unextendable wall tape measures (Kawe model), with the participants shoeless 
and in standardised conditions. Circumferences were measured using unextendable tape measures in standardised conditions. For obtaining elbow width measurements, a skinfold caliper was utilised.

\section{Fieldwork}

Fieldwork was initiated on 1 May 1998 and ended on 30 April 2000. Prior to conducting interviews, participants were sent a letter of introduction and invitation to collaborate by the study co-ordinators.

Interviewers were provided with a list of subjects to interview (complete name, address, telephone, age), and telephoned individuals to establish a time for the interview. When a subject on the list was not found at the given address, or census errors were encountered, s/he was replaced by another individual drawn from a list of substitutes. For each individual on the list, three contact attempts were made during various days of the week and at different times, either by phone or in person at the subject's home. In the case that the three attempts were unsuccessful, the subject was classified as a nonparticipant. Due to logistical problems, not all of the interviews planned for the cities of Jaen and Vigo were completed, and, as such, the theoretical sample was reduced to 5200 .

Home interviews were conducted by 43 dietitians and nutritionists who had undergone a rigorous selection, training and standardisation process. Survey data were entered by the same field-staff into laptop computers that had software specifically designed for the study. Completed interview data were periodically sent to the co-ordinating centres in Barcelona and Bilbao.

In the case of children aged 2 to 5 years, mothers or primary caretakers responsible for feeding the child responded to the interview questions. For children aged 6 to 13 , the children themselves answered the interviews, with support from the caretaker responsible for his/her feeding. When it was necessary, additional information was obtained from school lunch menus, by conducting telephone interviews with the food service director of the school.

\section{Quality control}

The periodic submission of field data to the co-ordinating centre allowed for the follow-up and control of fieldwork as it was being carried out. Probe questions were introduced in the interviews in order to estimate consistency of responses. Twenty per cent of the sample was interviewed by phone in order to verify some aspects of the dietary information and other data previously gathered by personal interview. Once data archives were reviewed, they were compiled into a database utilising the program ACCESS.

\section{Food composition table}

The nutrient database software used for the study consisted of the Spanish database from Mataix et al. ${ }^{15}$, completed with information from the French $^{16}$ and British $^{17}$ food composition tables.

\section{Statistical analyses}

Data were analysed using the statistical package SPSS for Windows version 10.0. Consumed foods recorded in the 24-hour recall were immediately classified into one of the following feedings: breakfast, mid-morning snack, lunch, afternoon snack, dinner and others. Foods classified as breakfast items in the study were derived from those foods listed in the breakfast section of the 24-hour recall. Data from the 24-hour recalls were adjusted for intraindividual variability in order to accurately estimate distribution of intakes and percentage of population groups above or below defined cut-off points (Reference Nutrient Intake, RNI) ${ }^{12}$.

For the identification of underreporting of food intake, we used the ratio of energy intake to basal metabolic rate (EI/BMR): a value of less than 1.14 classified the individual as an underreporter ${ }^{18}$. The reference nutrient values utilised were those elaborated by Centro Superior de Investigaciones Científicas (CSIC), Complutense University of Madrid ${ }^{19}$.

\section{Results}

A total of 3534 individuals participated in the study, which represented $64.4 \%$ of the theoretical sample and $68.2 \%$ of the final sample. The distribution by age and sex of the sample and the study population were not significantly different from the Spanish population for these age groups. Additionally, the distribution by regions maintained their original territoriality (Table 1).

Figure 1 reflects the population distribution according to the number of meals consumed by age group. It can be observed that the number of meals decreases with age. The percentage of the population who normally ate breakfast was 85.3\%; this figure diminishes with age, being higher in children aged 2 to 5 years $(92.7 \%)$ and less



Fig. 1 Number of meals a day by age groups in Spanish population aged 2 to 24 years 
Table 1 Distribution of the sample in relation with Spanish population by age groups and sex

\begin{tabular}{|c|c|c|c|c|}
\hline \multirow[b]{2}{*}{ Sex/age } & \multicolumn{2}{|c|}{$\begin{array}{c}\text { Spanish population } \\
(1997)\end{array}$} & \multicolumn{2}{|c|}{ enKid sample } \\
\hline & $n$ & $\%$ & $n$ & $\%$ \\
\hline \multicolumn{5}{|l|}{ Total } \\
\hline $2-5$ years & 1580205 & 13.3 & 385 & 10.9 \\
\hline $6-9$ years & 1624960 & 13.7 & 423 & $12 . c$ \\
\hline $10-13$ years & 1821810 & 15.4 & 567 & 16.0 \\
\hline $14-17$ years & 2227013 & 18.8 & 682 & 19.3 \\
\hline $18-24$ years & 4607571 & 38.8 & 1477 & 41.8 \\
\hline Total & 11861559 & 100.0 & 3534 & 100.0 \\
\hline \multicolumn{5}{|l|}{ Males } \\
\hline $2-5$ years & 816105 & 13.4 & 195 & 12.0 \\
\hline $6-9$ years & 839706 & 13.8 & 211 & 13.0 \\
\hline $10-13$ years & 937300 & 15.4 & 281 & 17.2 \\
\hline $14-17$ years & 1143057 & 18.8 & 337 & 20.7 \\
\hline $18-24$ years & 2360090 & 38.7 & 605 & 37.1 \\
\hline Total & 6096258 & 100.0 & 1629 & 100.0 \\
\hline \multicolumn{5}{|l|}{ Females } \\
\hline $2-5$ years & 764100 & 13.3 & 190 & 10.0 \\
\hline $6-9$ years & 785254 & 13.6 & 212 & 11.1 \\
\hline $10-13$ years & 884510 & 15.3 & 286 & 15.0 \\
\hline 14-17 years & 1083956 & 18.8 & 345 & 18.1 \\
\hline $18-24$ years & 2247481 & 39.0 & 872 & 45.8 \\
\hline Total & 5765301 & 100.0 & 1905 & 100.0 \\
\hline
\end{tabular}

in adolescents ( $82.1 \%$ in $14-17$ year olds) and in young adults ( $81.1 \%$ in $18-24$ year olds).

Tables 2 and 3 reflect the mean daily food, nutrient and energy intakes in the study population by sex. Energy consumption was $2189 \mathrm{kcal}$ in males and $1781 \mathrm{kcal}$ in females. Total fat as a percentage of total energy intakes was $39.8 \%$ and $13.4 \%$ for saturated fat, being identical in both sexes. Vitamin and mineral consumption was higher in males with the exception of vitamin C, which was similar. Only $5 \%$ of females in these age groups met the $200 \mu \mathrm{g} \mathrm{day}^{-1}$ folate requirement.

The food patterns shown in Table 3 reveal moderate milk consumption, high consumption of dairy products and meat (with respect to other age groups) intake, and low consumption of fish, fruit and vegetables.

\section{Discussion}

Many of the difficulties encountered in the qualitative and quantitative description of dietary intake in a community become more acute when dealing with a target population composed of children and adolescents. When one wishes to utilise information provided directly by the

Table 2 Daily intakes of energy and nutrients by sex in Spanish population aged 2 to 24 years

\begin{tabular}{|c|c|c|c|c|c|c|c|c|c|c|c|c|c|c|}
\hline & \multicolumn{7}{|c|}{ Males $(n=1629)$} & \multicolumn{7}{|c|}{ Females $(n=1905)$} \\
\hline & Mean & SD & P5 & P25 & P50 & P75 & P95 & Mean & SD & P5 & P25 & P50 & P75 & P95 \\
\hline nergy (kcal) & 2188.7 & 445.2 & 1496.5 & 1881.2 & 2185.0 & 2462.6 & 2922.3 & 1781.4 & 316.4 & 1302.3 & 1561.3 & 1768.7 & 1985.8 & 2312.2 \\
\hline Protein (g) & 94.8 & 19.0 & 61.6 & 81.6 & 96.9 & 107.1 & 124.3 & 76.7 & 11.7 & 58.2 & 69.6 & 76.2 & 83.6 & 97.0 \\
\hline Carbohydrate $(\mathrm{g})$ & 245.6 & 50.7 & 175.9 & 206.8 & 243.1 & 279.0 & 328.1 & 200.0 & 38.6 & 138.0 & 175.2 & ? 198.9 & 223.9 & 263.6 \\
\hline ipids (g) & 95.5 & 22.2 & 62.4 & 81.4 & 94.7 & 107.1 & 132.6 & 78.0 & 15.4 & 53.8 & 67.5 & 77.3 & 87.0 & 104.8 \\
\hline $\mathrm{FA}(\mathrm{g})$ & 32.1 & 7.3 & 21.9 & 27.1 & 31.5 & 36.0 & 44.6 & 26.3 & 5.8 & 17.9 & 22.5 & 26.0 & 29.8 & 36.9 \\
\hline MUFA (g) & 38.8 & 10.0 & 23.9 & 32.4 & 38.3 & 44.5 & 54.3 & 31.7 & 6.7 & 20.9 & 27.3 & 31.5 & 35.7 & 43.3 \\
\hline UFA (g) & 12.1 & 3.2 & 6.7 & 10.1 & 12.2 & 14.0 & 17.2 & 9.9 & 2.8 & 6.0 & 8.0 & 9.7 & 11.4 & 14.5 \\
\hline holesterol (g) & 400.9 & 153.2 & 200.6 & 287.8 & 376.8 & 487.8 & 679.4 & 323.9 & 132.8 & 139.1 & 29.8 & 3305.6 & 396.0 & 578.1 \\
\hline (a) & 16.4 & 4.0 & 10.7 & 13.6 & & 18.8 & & 13.8 & 3.2 & 8.5 & 11.8 & 13.7 & 15.5 & 19.1 \\
\hline (\% of energy) & 17.7 & 2.8 & 14.5 & 16.1 & 17.4 & 18.8 & 21.4 & 17.6 & 2.3 & 14.4 & 16.0 & 17.3 & 18.8 & 21.6 \\
\hline Carbohydrate (\% of energy) & 42.8 & 4.8 & 35.6 & 40.0 & 42.6 & 45.3 & 50.3 & 42.6 & 5.1 & 34.5 & 39.8 & 42.9 & 45.5 & 49.7 \\
\hline Fats (\% of energy) & 39.8 & 4.8 & 33.4 & 37.1 & 39.6 & 41.9 & 45.9 & 39.8 & 4.0 & 33.8 & 37.3 & 39.6 & 42.0 & 46.3 \\
\hline anoral & 13.4 & 1.9 & 10.7 & 12.2 & 13.4 & 14.5 & 16.3 & 13.4 & 1.9 & 10.7 & 12.2 & 13.3 & 14.4 & 16.9 \\
\hline y) & 16.1 & 2.4 & 12.6 & 14.7 & 16.0 & 17.5 & 19.7 & 16.2 & 2.1 & 12.9 & 14.8 & 16.1 & 17.4 & 19.7 \\
\hline PUFA ( & 5.0 & 0.9 & 3.7 & 4.5 & 5.0 & 5.5 & 6.5 & 5.0 & 1.0 & 3.6 & 4.3 & 4.9 & 5.5 & 6.8 \\
\hline Calcium (mg) & 952.7 & 196.5 & 677.8 & 833.7 & 930.5 & 1051.1 & 1287.7 & 827.5 & 163.5 & 581.6 & 724.8 & 3815.3 & 923.0 & 1092.2 \\
\hline & 14.4 & 3.1 & 9.1 & 12.4 & 14.4 & 16.3 & 19.4 & 11.8 & 2.1 & 8.2 & & 11.8 & 13.0 & 15.0 \\
\hline Ma & 286.8 & 52.8 & 210.8 & 251.1 & 283.5 & 317.4 & 372.9 & 247.6 & 39.1 & 183.6 & 224.2 & ? 249.1 & 268.9 & 310.3 \\
\hline Soc & 2577.6 & 659.8 & 1530.2 & 2168.8 & 2604.7 & 2911.1 & 3610.5 & 2012.2 & 442.6 & 1426.2 & 1707.2 & ? 1960.2 & 2223.0 & 2828.7 \\
\hline Pot & 2893.7 & 472.8 & 2132.0 & 2578.9 & 2892.5 & 3206.7 & 3667.8 & 2477.0 & 440.7 & 1766.1 & 2225.1 & 2463.8 & 2733.8 & 3222.6 \\
\hline Pho & 1497.6 & 256.2 & 1106.6 & 1323.4 & 1492.1 & 1649.7 & 1930.1 & 1268.0 & 183.6 & 972.2 & 1161.8 & 31270.5 & 5.5 & 1557.1 \\
\hline Vitar & 1.8 & 0.3 & 1.2 & 1.6 & 1.8 & 2.0 & 2.3 & 1.5 & 0.3 & 1.0 & 1.3 & 1.5 & 1.6 & 2.0 \\
\hline & 7.1 & 1.8 & 4.4 & 5.8 & 7.0 & 8.1 & 10.4 & 6.2 & 1.9 & 3.4 & 4.9 & 6.0 & 7.1 & 9.5 \\
\hline Thia & 1.4 & 0.3 & 1.0 & 1.3 & 1.4 & 1.6 & 1.9 & 1.2 & 0.2 & 0.9 & 1.0 & 1.2 & 1.3 & 1.6 \\
\hline in (mg) & 1.8 & 0.4 & 1.3 & 1.6 & 1.8 & 2.0 & 2.5 & 1.6 & 0.3 & 1.1 & 1.4 & 1.5 & 1.7 & 2.1 \\
\hline $\mathrm{Niac}$ & 23.8 & 4.7 & 14.6 & 21.0 & 24.8 & 27.1 & 29.9 & 20.0 & 4.1 & 12.9 & 17.7 & 20.2 & 22.5 & 26.3 \\
\hline & 161.6 & 42.4 & 96.9 & 132.1 & 157.6 & 186.9 & 235.3 & 144.9 & 32.9 & 92.7 & 123.0 & 144.6 & 166.1 & 199.2 \\
\hline Vitam & 8.1 & 1.9 & 4.7 & 7.0 & 8.2 & 9.3 & 11.1 & 6.7 & 1.2 & 5.0 & 5.9 & 6.7 & 7.5 & 8.7 \\
\hline Vitan & 77.5 & 32.9 & 34.9 & 52.8 & 73.0 & 96.3 & 139.0 & 75.6 & 30.9 & 33.7 & 52.3 & 72.5 & 93.7 & 132.8 \\
\hline Vitamin A $(\mu \mathrm{g})$ & 520.9 & 118.8 & 367.1 & 459.9 & 507.6 & 568.4 & 703.1 & 448.6 & 107.3 & 287.1 & 389.6 & 445.2 & 504.0 & 595.4 \\
\hline Vitamin D $(\mu \mathrm{g})$ & 2.1 & 0.6 & 1.2 & 1.7 & 2.1 & 2.4 & 3.2 & 1.6 & 0.6 & 0.8 & 1.2 & 1.5 & 1.9 & 2.7 \\
\hline
\end{tabular}

SD - standard deviation; P5, P25, P50, P75 and P95 - 5th, 25th, 50th (median), 75th and 95th percentile, respectively.

SFA - saturated fatty acid; MUFA - monounsaturated fatty acid; PUFA - polyunsaturated fatty acid.

Weighted estimations without excluding underreporters. Data adjusted for intra-individual variability. 
Table 3 Mean daily consumption of foods in Spanish population aged 2 to 24 years, by sex

\begin{tabular}{lrr}
\hline & Males & Females \\
\hline Milk & 316 & 281 \\
Yoghurt & 63 & 60 \\
Cheese & 26 & 21 \\
Other dairy products & 20 & 16 \\
Cereals & 216 & 158 \\
Pastry & 52 & 46 \\
Potatoes & 78 & 61 \\
Pulses & 23 & 19 \\
Fish & 50 & 45 \\
Red meat & 84 & 59 \\
Sausages & 53 & 40 \\
Poultry and rabbit & 41 & 38 \\
Eggs & 31 & 24 \\
Seasoning fats & 35 & 30 \\
Sauces & 19 & 15 \\
Fruit & 197 & 186 \\
Dry fruit and nuts & 5 & 5 \\
Vegetables & 86 & 95 \\
Sugars & 25 & 25 \\
Beverages without alcohol & 718 & 629 \\
Alcoholic beverages & 40 & 23 \\
\hline
\end{tabular}

Consumption in $\mathrm{g}$ or $\mathrm{ml} /$ person/day. Weighted estimations without excluding underreporters.

child, the most important factor to keep in mind is his/her cognitive development and the capacity for memory retrieval, conceptualisation and mathematical abstraction that the selected dietary evaluation tool requires. In general, children less than 12 years of age are considered to need adult assistance in order to adequately respond to dietary questionnaires ${ }^{20,21}$. An additional factor to consider when evaluating dietary intake in children is that, in dealing with a period characterised by change and development, dietary habits evolve quite rapidly.

In this unassuming exposition of results from The enKid Study, the primary intention was to delve into the methodological aspects of the investigation, as, in Spain, it constitutes the most important epidemiological study carried out in these age groups to date.

The dietary patterns and nutritional profile derived from enKid data reflect the changes in feeding habits and nutritional status that have occurred in Spain. It is precisely within the child and adolescent cohorts, more than any other age group, where the characteristics of the Mediterranean diet are unravelling ${ }^{22,23}$. The study design and sampling of the enKid study have the necessary methodological rigour required by these types of investigation. Moreover, both the fieldwork and statistical analysis were meticulously carried out and attended to.

Studies of this nature are of vital importance for the development of nutrition interventions directed towards this vulnerable population. Due to increased nutritional requirements for growth and development, as well as the sociological and behavioural changes brought on by the transition from the 20th to the 21st century, children and adolescents comprise an important nutritional risk $\operatorname{group}^{24,25}$.

\section{Acknowledgements}

The authors express their appreciation to all of the enKid team investigators, a project funded by Kellogg's España SA and Kellogg's Company, Battle Creek, USA via the Fundación Universitaria de Las Palmas de Gran Canaria and the Fundación para la Investigación Nutricional. The enKid Study Group was composed of: Directors - L SerraMajem and J Aranceta Bartrina; Co-ordinators - L Ribas Barba and C Pérez Rodrigo; Collaborators - R García Closas, L Gorgojo Jiménez, L Jover Armengol, J Ngo de la Cruz, L Peña Quintana, A Pérez Rodrigo, B Román Viñas and G Salvador Castells; Scientific Committee - Á Ballabriga Agudo (Universidad Autónoma de Barcelona), P. Cervera Ral (Centre d'Ensenyament Superior de Nutrició i Dietètica (CESNID), University of Barcelona), A Delgado (Universidad del País Vasco), JM Martín Moreno (Escuela Nacional de Sanidad, Madrid), J Mataix Verdú (Universidad de Granada), M Moya (Universidad Miguel Hernández) and A Sierra López (Universidad de La Laguna).

The authors also acknowledge additional support from:

E Casals Canudas; I Palma Linares; JJ Garre López; J González García; R del Llano Ribas; RD Vera García; J Almeida Rodríguez; and V Martín García.

\section{References}

1 Tojo R, Leis R, Queiro T, Pavón P. Dieta y otros factores de riesgo de hipercolesterolemia y aterogenicidad en la edad infantil. In: Marina C, Del Pozo J, Moran J, eds. Prevención Cardiovascular. Madrid: Ergon ED, 1995; 135-54.

2 Tojo R, Leis R, Pavón P. Dieta y perfíl lipídico en niños y adolescentes. Rev. Esp. Nutr. Comunitaria 1995; 1: 195-7.

3 Aranceta Bartrina J, Pérez Rodrigo C. Consumo de Alimentos y Estado Nutricional de la Población Escolar de Bilbao. Guias Alimentarias para la Población Escolar. Bilbao: Area de Salud y Consumo del Ayuntamiento de Bilbao, 1996.

4 Quemada Jorcano M. Valoración del estado nutricional de la población escolar de la Ciudad de Logroño, Doctoral thesis, Universidad del País Vasco, Lejona: $2000 .$.

5 Serra Majem L, Ribas L, García Closas R, Ramon JM, Salvador G, Farran A, et al. Libre Blanc: Avaluació de l'Estat Nutricional de la Població Catalana (1992-93). Barcelona: Departament de Sanitat i Seguretat Social, Generalitat de Catalunya, 1996; 1-252.

6 Vázquez C, De Cos AI, Martínez P, Jaunsolo MA, Román E, Gómez C, et al. Consumo de alimentos y estado nutricional de los escolares de la Comunidad de Madrid (CAEMPE): metodología general y consumo global de alimentos. Nutr. Hosp. 1995; 10: 40-8.

7 Iáñez MI. Valoración del estado nutricional de una población infantil escolarizada de Granada. Influencia del comedor escolar, Doctoral thesis, Facultad de Medicina, Universidad de Granada, Granada: $1997 .$.

8 Carazo E. Hábitos alimentarios, ingesta de nutrientes y valoración antropométrica de los adolescentes escolarizados de Granada. Experiencia piloto de educación nutricional, Doctoral thesis, Facultad de Ciencia, Universidad de Granada, Granada: 1992.

9 Serra Majem L, Armas Navarro A, Ribas Barba L. Equipo investigador de ENCA 1997-98. Encuesta Nutricional de 
Canarias 1997-98. Hábitos Alimentarios y Consumo de Alimentos. Vol. 1. Santa Cruz de Tenerife: Servicio Canario de Salud, 1999; 1-244.

10 Serra Majem L, Ribas Barba L, Armas Navarro A. Equipo Investigador de ENCA 1997-98. Encuesta Nutricional de Canarias 1997-98. Ingesta de Energía y Nutrientes y Riesgo de Ingestas Inadecuadas. Vol. 3. Santa Cruz de Tenerife: Servicio Canario de Salud, 2000; 1-221.

11 Gorgojo L, Guallar E, Martín-Moreno JM, López-Nomdedeu C, Vázquez C, Martí-Henneberg C, Serrano Rios M. Encuestas alimentarias en los niños españoles de edad escolar: análisis del período 1984-1994. Med. Clin. (Barc.) 1999; 112(10): 368-74

12 Liu K, Stamler J, Dyer A, McKeever J, Mckeever P. Statistical methods to assess and minimize the role of intra-individual variability in obscuring the relationship between dietary lipids and serum cholesterol. J. Chronic. Dis. 1978; 31(6-7): 399-418.

13 Aranceta J, Pérez-Rodrigo C, Eguileor I, Marzana I, Gonzalez de Galdeano L, Saenz de Buruaga J. Food consumption patterns in the adult population of the Basque Country (EINUT-I). Public Health Nutr. 1998; 1: 185-90.

14 Aranceta J, Pérez C, Amela C, García Herrera R. Encuesta de Nutrición de la Comunidad de Madrid. Madrid: Consejería de Salud de la Comunidad de Madrid, 1994.

15 Mataix J, Mañas M, Llopis J, Martínez de Vitoria E. Tabla de Composición de Alimentos Españoles, 3rd ed. Granada: Universidad de Granada, 1998.

16 Favier JC, Ireland-Ripert J, Toque C, Feinberg M. Repertoire Général des Aliments. Table de Composition. Paris: Lavoisier Tec+Doc, 1995
17 Holland B, Welch AA, Unwin ID, Buss DH, Paul AA, Southgate DAT. McCance \& Widdowson's The Composition of Foods, 5th revised and extended ed. Cambridge: Royal Society of Chemistry, 1991.

18 Goldberg GR, Black AE, Jebb SA, Cole TJ, Murgatroyd PR, Coward WA, Prentice AM. Critical evaluation of energy intake data using fundamental principles of energy physiology. 1. Derivation of cut-off limits to identify under-recording. Eur. J. Clin. Nutr. 1991; 45: 569-81.

19 Centro Superior de Investigaciones Científicas. Tablas de Ingestas Recomendadas en Energia y Nutrientes para la Población Española. Madrid: CSIC, Universidad Complutense de Madrid, 1994

20 Bingham SA, Nelson M. Assessment of food consumption and nutrient intake. In: Margetts BM, Nelson Meds. Design Concepts in Nutritional Epidemiology. Oxford: Oxford University Press, 1991; 153-265.

21 García Closas R, Serra Majem L. Encuestas alimentarias en la infancia. Arch. Pediatr. 2001 [in press].

22 Serra-Majem L, Ribas L, Lloveras G, Salleras L. Changing patterns of fat consumption in Spain. Eur. J. Clin. Nutr. 1993; 47(Suppl. 1): S13-20.

23 Serra-Majem L, Ribas L, Ngo J, Aranceta J, Garaulet M, Marin E, et al. Risk of inadequate intakes of vitamins A, B1, B6, C, $\mathrm{E}$, folate, iron and calcium in the Spanish population aged 4 to 18 Int. J. Vit. Nutr. Res. [in press].

24 Serra-Majem L. Vitamin and mineral intakes in European children. Is food fortification needed? Public Health. Nutr. 2001; 4(1A): 101-7.

25 Olmedilla B, Granado F. Growth and micronutrient needs of adolescents. Eur. J. Clin. Nutr. 2000; 54(Suppl): S11-5. 